Božidar Filipović ${ }^{1}$

Department of Sociology

Faculty of Philosophy

University of Belgrade
UDK: 347.23:17.035.1 Durkheim E.

316.334.3 Rousseau J.-J.

316.334.3 Kant I.

Прегледни научни рад

Рад примљен: 10.8.2016.

\title{
DURKHEIM ON INDIVIDUALISM AND PROPERTY RIGHTS: ORIGIN OF INSTITUTIONAL FRAMEWORK
}

Summary: In this paper we tried to point out to Durkheim's conception of individualism which was founded on the political philosophy of Rousseau and Kant. The last two authors are also important for the reconstruction of Durkheim's view on the origin and role of (private) ownership. We showed that his understanding of the origin of the institution of property directly related to the role which he intended for corporations in modern society. In Durkheim's case, meritocracy can be viewed through the lens of his aspirations for the realization of legal formal, but also "initial" material equality of all members of a society. Therefore, in the case of Durkheim's work, it can be understood as the pursuit of the realization of the principle that would imply permanent intervention of the state and corporation in order to ensure equal conditions for all.

Keywords: Durkheim, Property, Individualism, Rousseau, Dreyfus Affair

\section{Introduction}

The Dreyfus affair sparked a wave of anti-Semitism in France, and based on the testimonies of Durkheim's family members, one can say that it was felt even in a small town such as Épinal (Fournier, 2013: 286). Protests were organized in Bordeaux and other major cities, openly calling for the murder of Jews. Their shops were covered in posters calling for the boycott of all stores owned by Jews. Durkheim, however, did not show particular concern as a member of a vulnerable ethnic minority group. His fears were related to, in his opinion, much greater and more fundamental questions of the moral state of the French nation at the end of the 19th century.

In February 1898, in a letter to Marcel Mauss, Durkheim spoke openly about his views regarding the Dreyfus Affair (Durkheim, 1998: 110-112). He referred to the whole situation as extremely difficult, yet interestingly, for him anti-Semitism

\footnotetext{
${ }^{1}$ filipovic.bozidar1@gmail.com
} 
Božidar Filipović, Durkheim on Individualism and Property Rights: Origin of Institutional...

was merely an ephemeral phenomenon. What actually worried him was the situation in which such a "small thing" ("minceaffaire") caused great moral confusion in society. More precisely, Durkheim primarily targeted the reaction of the conservatives "who rose against all kinds of principles we believed we have adopted" 2 (Durkheim, 1998: 110). As a "remedy" in the political and intellectual struggle that was taking place before his eyes, he suggested the unity of all forces that were on Dreyfus' side - the symbol of the values which needed to be defended. On this occasion, he told Mauss that he would suggest the establishment of the rule of law $^{3}$ to Hubert (Henri Hubert).

The same year, Ludovic Trarieux, senator and former minister of justice, initiated the establishment of an association called The Human Rights League (Ligue pour la defense des droits de l'homme et du citoyen). Durkheim was the secretary of the association for the entire area of Bordeaux. Ever since the establishment of the League, he had been showing exceptional commitment to the association, and such a role of the already significant academic figure of the faculty in Bordeaux obviously did not agree with his political opponents. The paper Le Nouvelliste published an article in which Durkheim was directly accused of spreading the Dreyfus propaganda at the university, i.e. among his students ${ }^{4}$ (Fournier, 2013: 291). Mimica believed that Durkheim's involvement during the Dreyfus Affair contributed to his personal growth, which was, at the same time, beneficial for the entire process of institutionalization of sociology. To quote Mimica: "certainly the most respected administrators of the higher education system could not forget the zealous secretary of the League in Bordeaux who would so thoroughly and with obvious pleasure informed them of every new signature in support of the "Dreyfus matter" (Mimica, 2004: 208-209).

Reacting to Emile Zola's famous publication in the newspaper L'Aurore, Brunetière (Ferdinand Brunetière), a prominent literary historian, critic, and lecturer at the Ecole normale supérieure, made a series of accusations against the "intellectual". In the article Après le procès, he criticized intellectuals, as connoisseurs of a particular field of science or art, for aspiring after the right of authority regarding the issues for which they lacked competence (Mimica, 2004: 199). Attempting this, they deceived the public, because their arguments were supposedly based on science, which certainly could not be said to have clearly and unambiguously confirmed their views. For us, a fact more interesting than the

\footnotetext{
2“[...] Toutes sortes de principes qu'on croyait acquis[...]"

3"[...] ligue permanente pour le respect de la légalité [...]". occasion.

${ }^{4}$ The delegation of students later addressed the paper with the intent to deny their writing on this
} 
accusations against intellectuals is his attitude towards individualism which he openly and directly declared a threat. He believes that, "if this is the principle of our national army, we have the right to repeat it here again, it is not democracy that is the enemy, but individualism and anarchy" (Brunetière, 1898: 443). Immediately after this assertion, Brunetière declared individualism and anarchy the greatest enemies of democracy and the military.

\section{Cult of the individual}

The aforementioned can be viewed as (prior) context of Durkheim's work Individualism and the Intellectuals which was published in July 1898, in the magazine Revue bleue in response to the views of Brunetière (Fournier, 2013: 296). Therefore, Durkheim points out that "the recent intervention of a wellknown man of letters" (Durkheim, 1973: 43) represents the reason to answer questions which are, at the same time, of current, political significance, but also the reason to provide individualism with principal, theoretical, and sociological foundation. For him, not every foundation of individualism is equally legitimate or desirable. Seeking to justify the issue by the views of the most relevant philosophers which can be "used" in a debate, Durkheim begins with the dichotomy of two opposing concepts of individualism (Lukes, 1969: 15).

Durkheim finds the first concept in the thoughts of the old and well-known "enemies" of his view on society - utilitarists, "economists", and Herbert Spencer. The individualism of this sort represents the:

"crass commercialism which reduces society to nothing more than a vast apparatus of production and exchange. For it is exceedingly clear that all communal life is impossible without the existence of interests superior to those of the individual. We quite agree that nothing is more deserved than that such doctrines be considered anarchical" (Durkheim, 1973: 44).

Durkheim is obviously trying to dispute the aforementioned theories using the same discursive tools as his opponent Brunetière. He too sees anarchism as a scarecrow which, as we have already seen, has its cause in individualism. Yet, Durkheim did not express particular concern about such views because "if individualism had no other representatives, it would be quite useless thus to move heaven and earth to combat an enemy who is in the process of quietly dying a natural death" (Durkheim, 1973: 44).

In his wish to promote a different type of individualism as an established ideal, which he finds in the works of two famous philosophers, Durkheim points out: 
Božidar Filipović, Durkheim on Individualism and Property Rights: Origin of Institutional...

"But there exists another sort of individualism which is less easily overcome. It has been professed, for the past century, by the vast majority of thinkers: this is the individualism of Kant and Rousseau, of the idealists - the one which the Declaration of the Rights of Man attempted, more or less happily, to formulate and which is currently taught in our schools and has become the basis of our moral catechism" (Durkheim, 1973: 44-45).

Cladis states that, in fact, Durkheim has been trying all his life to reconcile the two views on individualism. The first one sees the individual as a radical and autonomous entity, while the second one sees the individual as "a socially determined bit of collective tissue" (Cladis, 1989: 275). The source of individualism is collective, or rather, it is religious in nature because the social order which constitutes its base is not only "a hygenic discipline or a prudent economy of existence; it is a religion in which man is at once the worshiper and the god" (Durkheim 1973: 46). It is important to emphasize that the cult of the individual is a sort of "worship" which does not address any particular individual, rather it is by nature "impersonal and anonymous", it "then, soars far above all individual minds [consciences particulières] and can thus serve them as a rallying point" (Durkheim 1973: 48).

The echo of Kant and Rousseau is obvious in the publication of the most important element of individualism, even though Durkheim in this case does not call explicitly on these two authors: "cult of man has as its primary dogma the autonomy of reason and as its primary rite the doctrine of free inquiry" (Durkheim, 1973: 49). It is enough to point out the basic elements of Kant's conception of enlightenment to realize the same role of reason in the creation or preservation of desirable vision of society and every individual in it. Kant begins his writing An Answer to the Question: "What is Enlightenment?" precisely with the answer from the title itself. In it, he clearly states:

"Enlightenment is man's emergence from his self-incurred immaturity.

Immaturity is the inability to use one's own understanding without the guidance of another. This immaturity is self-incurred if its cause is not lack of understanding, but lack of resolution and courage to use it without the guidance of another" (Kant, 1991: 54).

In order to defend the role of intellectuals which Brunetière so strongly contested, Durkheim recognizes and respects the authority based on knowledge, or rather necessity to follow "competent opinions" when "I can form no knowledgeable opinion" (Durkheim, 1973: 49). This does not cause an individual to lose their independence and autonomy in decision-making, because the agreement is established only when my mind is offered "reasons before it bows before someone 
else's" (Durkheim, 1973: 49), and, thus, the reason-based individualism most certainly does not encourage atomization or anarchy.

The attitude towards reason as a constitutive concept for understanding the emergence of society occurs in Rousseau's work as well. Man becomes his own master only when he reaches the age of reason, or if there is a capacity to be the only one to judge the means of preservation (Rousseau, 2002: 156). More importantly, reason is an irreplaceable instance on the way towards the exit from the natural state:

"This passage from the state of nature to the civil state produces in man a very remarkable change, replacing instinct by justice in his behavior, and conferring on his actions the moral quality that they had lacked before. It is only now, as the voice of duty succeeds to physical impulse and right to appetite, that man, who had previously thought of nothing but himself, is compelled to act on other principles, and to consult his reason before he attends to his inclinations. Although, in the civil state, he deprives himself of a number of advantages which he has by nature, the others that he acquires are so great, so greatly are his faculties exercised and improved, his ideas amplified, his feelings ennobled, and his entire soul raised so much higher, that if the abuses that occur in his new condition did not frequently reduce him to a state lower than the one he has just left, he ought constantly to bless the happy moment when he was taken from it forever, and which made of him, not a limited and stupid animal, but an intelligent being and a man" (Rousseau, 1999: 59).

Natural laws apply only in the case of beings endowed with it, and thus cannot apply to animals (Rousseau, 2002: 84). Reason is, therefore, not only the basis of individual independence, but also the whole social and moral order, as it is the source of universal justice (Rousseau, 2002: 178). Rousseau is aware of the fact that not everyone has the same intellectual capacity. Thus, some individuals need leaders to be able to realize or conform their desires to reason, while others, great legislators, use "reason which soars beyond the reach of common men" (Rousseau, 2002: 56). Common sense is the means by which we are able to recognize the common good as the only goal of the general will (Rousseau, 2002: 183).

But why is Rousseau's (and Kant's) understanding of the role of reason in the creation and preservation of the moral and social order important in connection with Durkheim's defense of the cult of the individual? As we have already seen, an individual and their rational reflection on their own situation is the focal point of transition from natural to social condition. This obvious premise is a place from which we want to start taking into consideration the problem of Durkheim's attempt to integrate Rousseau's heritage into his own social and political project. Mimica shows us how Durkheim's defense of individualism was compatible with 
his sociological realism (Mimica, 2004: 193), or, as Lukes says, Durkheim wanted to "cut the conceptual knot that has frequently been held to tie methodological individualism to liberalism, asserting both the autonomy of sociology and the sacredness of the individual" (Lukes, 1969: 19). We might be able to agree with this assumption, however, the establishment of the cult of the individual on the basis of the tradition of one or more natural law theories (Rousseau and Kant) without the intent to accept their basic assumptions, leads to certain problems ${ }^{5}$. The truth is, Durkheim himself was aware of the fact that his understanding of individualism differs from that of Rousseau and Kant. He, therefore, criticizes them because they "wanted to deduce their individualistic ethics not from society but from the notion of the isolated individual" (Durkheim, 1973: 231, footnote 4). But the question is to what extent is the reference to Rousseau and Kant justified in this case, and what is left of the tools and instruments that can be used in the fight against the utilitarian and atomistic vision of individualism, the one that Spenser and the "economists" promote?

We believe that individualism can be "defended" from the positions of sociological realism only if we ignore the evolutional elements of Durkheim's theory, which are centered around the problem intensely actualized only after the advent of the industrial revolution. It is a theme featured in the title of Durkheim's doctoral dissertation - clearly, we are referring to the division of labor and its consequences.

Durkheim is at least partially aware of the problem that occurs when the cult of the individual is established on the basis of Rousseau's philosophy. The problem is reflected precisely in the role of the individual in the constitution of society or political body:

"This eclecticism, it is said, is not without contradictions. To be sure, we do not dream of defending the way these different thinkers went about fusing these two aspects of their systems of thought. If, with Rousseau, we begin by making of the individual a sort of absolute which can and must suffice unto itself, it is evidently difficult then to explain how it was possible for the civil state to be established" (Durkheim, 1973: 47).

He regarded the entire corpus of the social contract theory as "fiction" that had no real basis in the course of historical events. Historiography does not reveal any clues that would have us consider such a model of the emergence of society. The misconception comes from the assumption that every social relationship in

\footnotetext{
${ }^{5}$ Among well-known sociologists Erving Goffman was also conceived individual as a deity or sacred "object" (Goffman, 1967: 95; Spasić, 1996: 63-66).
} 
which there is no compulsion or coercion can be regarded as a certain type of contract established by the mere fact that the adult individual continues to live in the same political body in which they were born (Durkheim, 1972: 219). Durkheim finds the source of this misconception in the idea that the coercion in lower "societies" holds a far more important place than in the later stages of evolutionary development. It is clear that, in this case, he aims at Spencer's dichotomous typology between the militaristic and industrial type of society (Offer, 2010: 223-252; Mingradi, 2011: 58).

It is precisely in the context of the debate with Spencer that Durkheim indicates the most significant distinction in the attitude towards Rousseau's theory of social contract:

\begin{abstract}
"By this Spencer does not mean that society ever rests upon an implicit or formal contract. The hypothesis of a social contract is, on the contrary, irreconcilable with the principle of the division of labor. The greater the importance one ascribes to the latter, the more completely must one abandon Rousseau's postulate. This is because for such a contract to be feasible, at any given time all individual wills should be in agreement regarding the common foundations of the social organization and consequently every individual consciousness should pose to itself the political problem in all its generality. But in order to do this each individual must step out from his own sphere; all should equally play the same role, that of the statesman and the constituent member of society. Imagine to yourself the moment when society is making the contract: if assent is unanimous the thoughts of every consciousness are identical. Thus, in so far as social solidarity arises from such a cause, it has no connection with the division of labour" (Durkheim, 1994: 150).
\end{abstract}

The above passage represents perhaps the most explicit confirmation that, for Durkheim, the term (general or individual) will is equivalent to (general or individual) consciousness. But what is more significant for us, in terms of understanding the cult of the individual, is the relationship between the division of labor and collective consciousness. But before we deal with this problem, it should be mentioned that Durkheim assumed the unanimity of all consciousness in the very act of entering into a social contract. He was certainly well aware of the fact that, for Rousseau, a social contract is an underlying act of establishing a political community, nevertheless, it still refers to a general and formal framework within which different and even conflicting wills can emerge and be articulated. If the state is adequately regulated and all the evils of political life are eliminated, individual wills will "pour" into a general will as the articulation of the common good. Therefore, the consent of individual wills in the event of the conclusion of the social contract does in no case mean that the differences between individuals are 
either permanently or completely erased. The social contract is merely an assumption of the mechanism for the harmonization of these differences, and not the basis of their absolute negation (Rousseau, 2002: 163).

With this in mind, we can say that Durkheim's cult of the individual does not assume any less of a consensus among all citizens, because it is again a matter of an abstract frame (Durkheim, 2007: 46) with its final goal of freedom of each individual. If the social contract is incompatible with the consequences of the division of labor in terms of the relationship ${ }^{6}$ between the individual and collective consciousness, we find that the problem arises in equal measure in the case of the cult of the individual as well. Using Durkheim's terminology, we cannot find any "morphological" basis for the occurrence and survival of this cult:

"Thus, we make our way, little by little, toward a state, nearly achieved as of now, where the members of a single social group will have nothing in common among themselves except their humanity, except the constitutive attributes of the human person (personne humaine) in general" (Durkheim, 1973: 51).

In this case, social solidarity occurs only on the ground of mere human likeness, without any common social base (see also: Marske, 1987; Schiermer 2014). Therefore, we cannot accept a possible argument about the relatively small role of collective consciousness in the integration of societies with organic solidarity, since it is irrelevant for this particular case. In his work The Division of Labour in Society, Durkheim would often emphasize the decline in significance of the collective consciousness with the progress, or evolutionary development of society, but he never clarified the dual understanding of the relationship between the "base" and "superstructure", i.e. between the morphological base and collective consciousness. How is it even possible that the collective consciousness persists despite the structural differentiation (complexification) of the whole society as a consequence of the division of labor, if the collective consciousness is the product of social similarities among members of a community?

It is difficult to defend the thesis of gradual "emptying" of the scope of the content of collective consciousness. Such reading of Durkheim would mean that its content is gradually lost and/or becomes more and more abstract with the development of the division of labor. The assumption, however, implies that the cult of the individual has always been present as part of its content, and that it appeared and "denuded" over time as a residual minimum of social consensus. One does not need to know Durkheim's work in detail to notice the problematic nature of such argumentation:

${ }^{6} \mathrm{We}$ are referring to agreement, compatibility, or difference. 
"In societies where this [mechanical] solidarity is highly developed the individual, as we shall see later, does not belong to himself; he is literally a thing at the disposal of society. Thus, in these same social types, personal rights are still not yet distinguished from 'real' rights" (Durkheim, 1994: 85).

It is impossible to reconcile this view of individual rights with Durkheim's ideal of the cult of the individual. This, however, is not the only place where Durkheim does the "inversion" of Rousseau's understanding of the relationship between the individual and collective. In the case of the Dreyfus Affair, it was not the property rights and the aforementioned real rights of its main actors that were in the spotlight. Personal property as a right was not in the repertoire of topics of dispute between the parties, despite the fact that anti-Semitism was fed by alleged or actual differences in the material situation of the Jews in relation to the rest of the society. It might be that the consideration of the origin of property rights best demonstrates just how much Durkheim owes Rousseau, and to what extent he differed from him in terms of the relationship between the individual and collective.

\section{Theory of value and property}

Although he largely gained his scientific reputation thanks to a topic that had previously been the domain of the economy - the division of labor - his analyses of other fundamental questions of the "neighboring" science remained on the sideline and was less discussed in the literature. Such questions are the theory of value and origin of the institution of property to which he devotes attention during his lectures at the University of Bordeaux (1890-1900) that will later be published under the title Professional Ethics and Civic Morals (Leçon de sociologie).

Trying to explain the foundation and logic of the institution of property, Durkheim begins his discussion with the idea of property ${ }^{7}$ as a product of human activity, or the product of labor as its "crystallized" form ${ }^{8}$. Durkheim argues that this view has an obvious assumption as a starting point - the product of labor must belong to whom belongs the very ability, i.e. energy required for its creation. The goods which an individual creates are as much their property as the aforementioned capacity (Durkheim, 1950: 145). As an illustration of this view of property Durkheim points to John Mill's theory of value (John Stuart Mill, 1806-1873) and his intention of offering a solution to the old problem of economic science - the source of value. As the name itself suggests - the labor theory of value - he takes labor as its only source, which Durkheim sees as a problematic premise for several

\footnotetext{
${ }^{7}$ Here, we will use the terms property and ownership as synonyms

${ }^{8}$ The direction of his discussion contributed to indiscrimination of the questions of the economic theory of value and origin of a legal institution - ownership (property).
} 
reasons. His remarks in the debate that is not conducted exclusively with Mill ${ }^{9}$ can be divided into three parts.

The first part concerns the very labor theory of value, the second part concerns the relationship between labor as a source of values and the institution of property, and the third part concerns the problem of distribution, or general stronghold of the legitimation of this institution. It should be noted that the first part of the controversy can be differentiated from the second part solely on the analytical level, since there is no strict distinction between problematizing these topics in the field of production on the one hand, and distribution on the other. This "confusion" is mitigated by the direct reference to a quote from Mill's work Principles of Political Economy (Mill, 1885: 200), where there actually occurs the idea of the desired meritocratic idea of the distribution of property on the basis of the capacities demonstrated in market conditions (Durkheim, 1950: 145).

In the first part of his review Durkheim's remarks on the labor theory of value are not particularly original. He asks those who find the source of economic goods in labor: how is it possible that the value of a particular product (property) increases, without the owner himself lifting a finger (Durkheim, 2003: 126)? The property owner might suffer the same fate, only with the opposite outcome, in the form of outdated technology which significantly loses its value with the discovery of more modern equipment. However, one must admit that Durkheim had a more benevolent attitude towards the labor theory of value in The Division. The argumentation on unfair contracts or terms of exchange of goods and services virtually coincides with the argumentation provided by Marxism (Durkheim, 1972: 370372). In any case, we can say that Durkheim was aware of the multitude of factors that affect the final value of goods.

More important for us, however, is his criticism of (Mill's) theory of property as the exclusive product of labor. Interestingly, Durkheim finds both liberals and socialists in such a view, since they equally emphasize labor and capability as the basis of its (re)distribution. For Durkheim, however, property cannot belong exclusively to the individual who creates it, because "We do not belong to ourselves entirely: we owe something of ourselves to others, to the various groups we form part of" (Durkheim, 2003: 122). Durkheim then continues his argumentation by asking questions - if we give the best we have to the social groups to which we belong, why not give the material products of our work too; sometimes society requires from an individual to lay their life, why not also the goods that belong to that individual (Durkheim, 1950: 45)? Furthermore, it explicitly rejects any objec-

\footnotetext{
${ }^{9}$ Durkheim considers the understanding that property derives from labor widespread (Durkheim, 2003: 121).
} 
tion saying that the restriction of the right to property would conflict with the cult of the individual, i.e. cult of the personality [le culte de la personne humaine] (Durkheim, 1950: 146).

In addition, an individual does not owe or attain property through his work only, no matter how we understand market dynamics and whether or not we are supporters of the labor or subjective theory of value. Property can never be reduced to mere work because it has its social function which limits the possibilities for its holder. There are situations in which the disposal of property is limited considering the specific circumstances affecting the owner of the property, all in order to protect their interests ${ }^{10}$.

\section{Inheritance and corporation}

Regardless of the expressed skepticism about the state as a potential holder and regulator of collective ownership (Durkheim, 1971: 259), Durkheim saw the institution of inheritance as an archaic leftover with no basis in the morality of modern society (Durkheim, 1950: 254). More precisely, Durkheim is particularly opposed to the ab intestate inheritance, which in no way connects the reward (property) to merit. Aware of the fact that an institution that has existed for so long (transfer of property between different generations within the same family) cannot disappear so quickly and easily, he proposes a "compromise solution" that would imply the possibility of inheriting a limited part of property ${ }^{11}$.

As a solution to the problem of existing regulation of inheritance, the institution of corporation occurs with the mission to manage the property "surplus" that would appear due to the aforementioned restrictions. Everything that cannot be transferred to descendants of a deceased holder (or any other person or entity based on a will) remains the collective property of the corporation. Due to its inertness and distance from the needs of everyday life, the state would be a worse solution than inheritance within a family (Durkheim, 1971: 259). It is too far from each individual and cannot represent the optimal solution for such a complex task (Durkheim, 2003: 218). On the other hand, the family is no longer suitable due to its questionable stability and durability as a result of interrupted continuity - in economic terms - between the generations (Durkheim, 2003: 218). Therefore, Durkheim predicts corporations (groupes professionnels) as collective property managers ${ }^{12}$, which would otherwise be subject to inheritance within several gene-

\footnotetext{
${ }^{10}$ In short, and using the contemporary legal terminology, here Durkheim has in mind the absence of the owner's legal capacity.

${ }^{11}$ Aware of the fact that it was very difficult to determine the value which the descendants could legitimately inherit, Durkheim left this issue aside.

${ }^{12}$ More precisely, of the part which is greater than the given "maximum".
} 
Božidar Filipović, Durkheim on Individualism and Property Rights: Origin of Institutional...

rations of a family. Thus, equality would never be absolute, instead the differences in the wealth and income (or other privileges) would occur based on each individual's personal merit. In normative terms, the aforementioned may even represent the most radical position in Durkheim's overall work.

But the third part of the controversy is the most interesting for us - the question of the final establishment of ownership, or the source of its legitimacy in general. Referring to Kant, Durkheim sees work only as an "external sign of possession" (Durkheim, 1950: 156). Formally and legally, apart from work, property can be acquired by exchange, donation (gift), and succession as well. In the first case the exchange of products cannot create new value per se, but given that the terms of exchange are not ideal, it creates "asymmetric" outcomes as a result of unfair conditions on the market. Durkheim never offered a coherent explanation of what the "just" or fair, and what the "unfair" terms of exchange are. Durkheim does not limit the fairness of conditions of contract conclusion and exchange only to the absence of violence: "All constraint must therefore be absent. But where does constraint begin? It does not consist only in the direct use of violence, for indirect violence suppresses freedom equally effectively" (Durkheim, 1994: 317). Although he is aware that the working class is affected by the same circumstances in relation to the owners of capital (Durkheim, 1972: 371-372), Durkheim does not propose Marxist solutions in terms of possible change of such a situation.

If work cannot be the (only) basis for justification and understanding of the historical genesis of the institution of property, where can we find its foundations? In addition to considering Mill's "economic" theory of the origin of property, Durkheim tackled another view on this issue. Another view on the emergence of property with which he debates argues that the origin has its base in the will of an individual expressed as a legitimate right to own potential property. But, interestingly, Durkheim takes Kant as the "selected" representative of the aforementioned theory of the origin of property, while Rousseau appears only in passing, as a secondary "figure" in the debate. The fact is all the more interesting, given that Durkheim actually follows Rousseau's thread of argument on the origin and explanation of the legitimacy of the institution of property.

By referring to Kant, Durkheim indicates that the possibility of defining property is clear in a situation where an individual is physically attached to the object of ownership (for example, when they are holding it in their hands). However, if the will (or its free expression) is the basis for the constitution of property, the connection between the object of ownership and the individual who pretends to it must be of intellectual nature (Durkheim 1950: 151). Given the fact that the will is not limited in terms of space and time, the question arises concerning mutual coordination of different actors who can express their pretentions to the same 
object. Interestingly, in order to explain the origin of this problem, Durkheim uses the same thought experiment as Rousseau:

"Let us suppose that the earth were an infinite plain, and that human beings were dispersed over it in such a way that they did not form any community amongst themselves: in these conditions it would not be possible for them to have any possession in common. But the earth is spherical and hence of limited surface area. Men are thus compelled by the unity of habitat to be in relation - thus they form a whole and this whole is the natural owner of the total habitat which it occupies, that is, of the earth" (Durkheim, 2003: 129).

But Durkheim is aware of the fact that the individual will cannot be a law for other wills which can also pretend to the same piece of land or some other desirable object. In such a situation, the property can be based on the "right of the stronger", i.e. the ability to defend the possessed part of the land or object by the use of physical strength of each individual. Like many theoreticians of the social contract, Durkheim too emphasizes (repeats) the issue of sustainability of the "right" acquired in such a way. The property remains in the hands of the given individual only for as long as they have the strength and ability to defend it from the attacks of others. Therefore, a "collective will" is needed [une volonté collective], superior to any individual will (Durkheim, 1950: 153), which would represent the ultimate source of legitimacy of the right to property. Historically, the foundation of this institution - not surprisingly - Durkheim finds in religion.

But before comparing Rousseau's view of the relationship between property and the general will to Durkheim's explanation of the origin of ownership, we must clarify the way in which the last of the two determines the institution which is at the center of his attention. Durkheim divides the right to property into jus utendi, jus fruendi, jus abutendi (Durkheim, 1950: 165). However, Durkheim finds the true quality of the right to property only in the possibility of "isolation" or separation of objects of ownership from other members of society, who could possibly appear as its potential users. In modern societies, only the state (and lower levels of the government) can, under certain conditions, appropriate, or exclude the ownership ${ }^{13}$ from legal transactions (Durkheim, 1950: 169). This idea is very important because it gives Durkheim an additional argument for his French society reform project which would obviously imply the corporation as a "guard" and intermediary in the redistribution of property.

To declare a certain object sacred and forbidden to all members of society, except for one particular group or individual, is the essence of the principle of

${ }^{13}$ In this case, Durkheim primarily refers to the right to land ownership. 
Božidar Filipović, Durkheim on Individualism and Property Rights: Origin of Institutional...

taboo (Durkheim, 1950: 170). In considering the origin of property rights, Durkheim takes land as its first form. He finds the confirmation that the right to property is indeed a result of the taboo in religious prohibitions and rituals that perceive parcel boundaries as holy and sacred places. To violate the prohibitions concerning the established boundaries was the act of sacrilege that required severe punishment. Referring to the research of Fustel de Coulanges, Durkheim cites examples from the customs and religious practices of antiquity, when the narrow belts in land properties represented boundaries and therefore remained untreated. Such parts of property represented the holy land that were not to be processed, because plowing was considered taboo violation and disrespect of the gods. So frequently emphasized an idea of religion as a means or medium by which society presents itself to its members occurs in this case again, which actually means that society as a whole appears as the ultimate rightsholder (Durkheim, 2003: 190).

\section{Rousseau and Durkheim}

When we put aside the individualist premises of Rousseau's theory of state formation (and thus the institution of property), the similarity between the two concepts become much greater and more significant. There is a sort of "medley" present in Rousseau's work in understanding the role of private ownership (Bertram 2004: 89). It is, at the same time, a source of injustice, but also an incentive for the establishment of a (just) state. We will not devote attention to all details of his attitude towards this institution at this point because we are really only interested in its particular aspects. When the problem of ownership is viewed in the context of its constructive efforts to create a social contract, we can discern the contours of the idea of finding a fair solution for its establishment. Even more than that, it is the reason for the emergence of "civil society" (Rousseau, 2002: 113), and the state actually occurs as a result of the need for preservation and lasting solution to the issue of land ownership. When the entire problem is viewed from this perspective, the complex process of state formation merely seems like a transit point that transforms the right of first occupancy into property (Rousseau, 2002: 167-168). The distinction between the right of first occupancy and property is significant because Durkheim's understanding of the origin and nature of property exhibits typical similarities to Rousseau's conception of the term.

Where we can find the similarities between the two concepts of the origin of the institution of property? In Durkheim's case we cannot find a discourse on the natural state, however, there is the idea of society as the original and sole owner of the entire immovable property (land). As we have seen, society is the guarantor of the principles of the division of land. It does not grant the right to property to "first" title holders, instead it establishes the principle of mutual recognition of the 
same right of other members of society. The taboo as a "model" by which, according to Durkheim, the institution of property is created implies its universal validity, because no one must "exceed" the set boundaries apart from land owners themselves. Ownership, thus, requires a kind of social reality (religious system) which precedes it. Once again we emphasize that Durkheim never claimed that the entire (land) ownership has the property of sanctity, because this attribute actually belongs only to its boundaries.

Rousseau's individualistic assumptions require a series of explanations of how and why social condition is created, because, for him, it does not represent a given fact from which we start - as in Durkheim's case. The right of first occupancy which serves as a basis for possession is "more real than that of the strongest", but "becomes a true right only after the establishment of the right to property" (Rousseau, 2002: 167). The right of first occupancy is based on the following:

"In general, the following conditions are required in order to justify the right of first occupancy for a given piece of land. First, the land must as yet be uninhabited; secondly, no more must be occupied than is needed for subsistence; and in the third place, possession must be taken not by empty ceremonies, but by work and cultivation, the only mark of ownership which ought, in default of juridical title, to be respected by others" (Rousseau, 1999: 60-61).

In these conditions we find the idea of limiting the greed to acquire property which implies that the future ownership is divided according to the needs sufficient for the survival of each individual. On the other hand, farming, or labor is a sign of legitimacy of distribution. It is clear that such conditions create the basis that cannot be reduced only to legal equality (before the law), which, in Rousseau, unlike Kant ${ }^{14}$ (Basta, 2001: 23), merely represents a part of the general ideal of egalitarianism.

But the first of these conditions is the most interesting because it leads us to Rousseau's explanation of the emergence of a social contract. Only when there is no more free, unpossessed land do sensible requirements for ensuring the right of possession appear. Fearing that they will lose the piece of land they cultivate, everyone recognizes that only foundation in law can ensure peaceful enjoyment of property $^{15}$ (Rousseau, 2002: 121). It might be needless to say, but this right must be a product of the general will. When the conditions for the formation of a social

\footnotetext{
${ }^{14}$ On whom Durkheim calls much more frequently in his lecture dedicated to the question of ownership (Durkheim, 1950: 144-200).

${ }^{15}$ We should also mention that, for Rousseau, land is the first and most important object of ownership.
} 
contract are created (the question of ownership is certainly not the only impetus for its establishment), the entire possession passes into the hands of the state:

"Each member of the community, at the moment of its formation, gives himself to it as he then is, together with all his resources, of which the goods he possesses are part. It is not that, by this act, possessions change their nature as the possessor changes, so as to become property in the hands of the sovereign. But, just as the resources of the state are incomparably greater than those of one individual, so too public possession is, in fact, stronger and more irrevocable, although - at least for foreigners - it is no more legitimate. For the state, as regards its members, is master of all their property through the social contract, which in the state acts as the basis of all rights; but as regards other powers it is master only by the right of the first occupant, which passes to it from private individuals" (Rousseau, 1999: $60)$.

\section{Conclusion}

Thus, as in the case of Durkheim's view on the origin and nature of the institution of property, Rousseau also sees its foundation in the community. As opposed to the right of first occupancy, ownership implies the recognition of the right to possession of all the other signatories of a social contract of everything that is not part of another individual's property. For Rousseau, the act of establishment of the institution of property is actually the recognition of the right to legitimate separation of a certain object from collective ownership. We have seen that, for Durkheim, the way in which the taboo functions has the same logic - in both cases, the collectivity is the source, guardian, and arbiter of the right to property. Nevertheless, there are also differences that arise between the two authors. Given that we cannot observe the "phase" of natural state and right of first occupancy in Durkheim, the origin of this institution does not bear the individualistic stamp, as in Rousseau's case. Simplified and schematically shown, in Rousseau's case, the ownership goes from the individual to collectivity (state), only to return again to each of the individuals who, by their wills, created a political body. In Durkheim's case, the path is different and goes from the collective (religious communities of "lower societies", and later states) to the individuals who were granted this right through the mechanism of taboo, and eventually back into the hands of the collective entity - corporation ${ }^{16}$. However, if we limit our view only to the ownership, in the full sense of the word, the differences seem smaller.

${ }^{16}$ The last is certainly the normative part of Durkheim's views. 
If Rousseau can be said to have intended to establish the principles of justice, equality, and meritocracy at the very beginning of the distribution of property (land), by introducing the aforementioned criteria (Rousseau, 2002: 167-168), we can say that Durkheim wanted to preserve the same principles by the continuous "circulation" of ownership between the individual and the state (corporations). Insisting on the labor theory of value and right to property as the exclusive result of labor would not leave Durkheim much room for the justification of the role which he intended for the corporations. By restricting the right of succession, Durkheim opens the door to the permanent reactualization of Rousseau's concept of the role of the state as the guardian of the depositorium of collective property which was actually "lent" to individuals to use.

We can say that Durkheim's view on social justice is based on the collectivist premises, both in terms of (historical) origin of rights and their attitude towards the institutions that are supposed to earn and guarantee them. While the state is the most significant actor for individual (non-economic) rights, Durkheim intends the role of the regulator of the economic life of modern society for the corporation (Hawkin, 1994: 465). The redistribution of "surplus" wealth is intended precisely for the corporation, because it is more closely familiar with and directly involved in the society's economic flows than the state itself. Thus, the purpose of the corporation is not exhausted in the efforts to prevent the occurrence of anomy in modern society through the regulation of economic life. Its role is of fundamental importance for the realization of meritocratic principles. In contrast to the liberal conception of meritocracy, Durkheim thinks that it cannot rest solely on the formal or legal equality. Durkheim finds the legitimacy of the redistributive role of the corporation with respect to the restrictions on the right of succession in religious (eo ipso collective) roots of the institution of property. Regardless of Durkheim's collectivist assumptions, on the one hand, and Rousseau and Kant's individualistic departures on the other, we have shown that these authors share some of the key points in the attempts to explain the roots of basic human rights and the institution of property. This comparison gives us insight into Durkheim's realism from a new angle. 
Božidar Filipović, Durkheim on Individualism and Property Rights: Origin of Institutional...

\section{REFERENCES:}

Basta, D. (2001). "Kant kao politički mislilac”, In: Danilo Basta (prir.), Večni mir i carstvo slobode. Beograd: Plato, pp. 8-35

Bertram, C. (2004). Rousseau and the Social Contract. New York: Routledge

Brunetière, F. (1898): Après le procès. Revue des Deux Mondes. $<\mathrm{https} / / /$ fr.wikisource.org/wiki/Apr\%C3\%A8s_le_proc\%C3\%A8s>, accessed on September 19, 2016

Cladis, M. S. (1989). Durkheim's Communtarian Defense of Liberalism. Soundings: An Interdisciplinary Journal, Vol. 72, No. 2/3, pp. 275-295

Durkheim, E. (1950). Leçons de sociologie: physique des mours et du droit. Paris: Presses universitaires de France

Durkheim, Emile (1971). Le socialism. Paris: PUF

Durkheim, E. (1973). Individualism and the Intellectuals, In: On Morality and Society: Selected Writings. Chicago: The University of Chicago Press

Durkheim, E. (1994). The Division of Labour in Society, London: Macmillan Press

Durkheim, E. (1998). Lettres a Marcel Mauss, Paris: PUF

Durkheim, E. (2003). Professional Ethics and Civic Morals. London and New York: Routledge Fournier, M. (2013). Emile Durkheim: A Biography. Cambridge: Polity

Goffman, Erving (1967). Interaction Ritual: Essays on Face-to-Face Behavior. New York: Pantheon Books

Hawkins, M. J. (1994). Durkheim on Occupational Corporations: An Exegesis and Interpretation, Journal of the History of Ideas, Vol. 55, No. 3, pp. 461-481

Kant, I. (1991). An Answer to the Question: 'What is Enlightenment'?, In: Political Writings, Cambridge: Cambridge University Press

Kant, Immanuel (1991). Political Writings. Cambridge: Cambridge University Press

Lukes, S. (1969). Durkheim's 'Individualism and the Intellectuals, Political Studies 17: 14-30

Marske, C. E. (1987). Durkheim's 'Cult of the Individual' and the Moral Reconstitution of Society. Theory Vol. 5, No. 1, pp. 1-14

Mill, J. S. (1885). Principles of Political Economy. New York: D. Appleton And Company

Mimica, A. (2004). Emil Dirkem i radikalska sociologija. Beograd: Zavod za udžbenike i nastavna sredstva

Mingradi, A. (2011). Herbert Spencer. New York: Continuum

Offer, J. (2010). Herbert Spencer and Social Theory. New York: Palgrave Macmillan

Rousseau, J. J. (1999). Discourse on Political Economy and The Social Contract. Oxford: Oxford University Press

Rousseau, J. J. (2002). The Social Contract and The First and Second Discourses. New Haven and London: Yale University Press

Schiermer, B. (2014). Durkheim's Concept of Mechanical Solidarity - Where Did It Go?, Durkheimian Studies Vol. 20, pp. 64-88

Spasić, Ivana (1996). Značenja susreta, Goffmanova sociologija interakcije. Beograd: IFDT, "Filip Višnjić" 


\section{Божидар Филиповић}

Одељење за социологију

Филозофски факултет

Универзитет у Београду

\section{ДИРКЕМ О ИНДИВИДУАЛИЗМУ И ПРАВУ СВОЈИНЕ: ПОРЕКЛО ИНСТИТУЦИОНАЛНОГ ОКВИРА}

Сажетак: У раду смо покушали да укажемо на Диркемово схватағе индивидуализма које је утемељено у политичкој филозофији Русоа и Канта. Последња два аутора су значајна и за реконструкцију Диркемовог виђења порекла и улоге (приватне) својине. Показали смо да је његово схватање порекла институције својине у директној вези са улогом коју је наменио корпорацијама у савременом друштву. Друштвена правда се у случају Диркема може посматрати кроз призму његове тежне за остваривањем правно-формалне, али и „почетне“ материјалне једнакости свих припадника једног друштва. Она се, дакле, у случају Диркемовог дела може схватити као тежњ за остваривағем меритократског принципа који би подразумевао перманентну интервенцију државе и корпорације ради обезбеђивања једнаких услова за све.

Кључне речи: Диркем, својина, индивидуализам, Русо, Драјфусова афера 